\title{
Laxative effect of the crude methanolic extract of Polyalthia suberosa (Roxb.) Thwaites in mice
}

\author{
Md. Abdullah AZIZ1* (D), Nelufar YASMEN1 1 (D), Mst. Irin AKTER 2 (D) \\ 1 Department of Pharmacy, Jashore University of Science and Technology, Jashore-7408, Bangladesh. \\ 2 Department of Pharmacy, Stamford University Bangladesh, 51, Siddeswari Road, Dhaka-1217, Bangladesh. \\ * Corresponding Author. E-mail: a.aziz@just.edu.bd (M.A.A.); Tel. +880-175-956 4289.
}

Received: 15 April 2020 / Revised: 10 August 2020/ Accepted: 14 August 2020

\begin{abstract}
Polyalthia suberosa (Roxb.) Thwaites is traditionally used as abortifacient, laxative, febrifuge, analgesic, anti-HIV as well as filler's of tooth cavities. The present study was directed to evaluate laxative activity of the methanolic extract of Polyalthia suberosa (Roxb.) Thwaites leaves (PSM). A variety of tests including laxative activity test, laxative activity on loperamide-induced constipation in mice and gastrointestinal motility test in mice were utilised to evaluate the laxative activity of PSM. PSM at 200 and $400 \mathrm{mg} / \mathrm{kg}$ doses, expressed laxative activity in Swiss albino mice. Laxative effect of PSM evaluated by laxative activity test exposes that PSM possesses laxative activity at both doses. PSM also showed effectiveness against loperamide induced constipation. In addition, this extract produced significant intestinal transit ( ${ }^{*} \mathrm{P}<0.05$ vs. control) at both doses. The results of this study provide support for the traditional use of Polyalthia suberosa (Roxb.) Thwaites leaves as a laxative.
\end{abstract}

KEYWORDS: Laxative, constipation, Polyathia suberosa (Roxb.) Thwaites, Swiss albino.

\section{INTRODUCTION}

As a gastro-intestinal disorder, constipation affects $8-15 \%$ of mass population [1]. Constipation describes infrequent bowel movements, where a person has fewer than three bowel evacuations in a week or evacuating with stools that are rigid, dry and less in amount. In this case, evacuation of stools becomes painful or difficult [2]. It may arise due to drugs, deficiency of fiber, anorectal as well as metabolic problems. However, laxatives hold water within the bowel lumen through osmotic effects or excite intestinal secretion or motility that increases the volume of intestinal contents, so that not only incidence but also trouble-free defecation is raised [3]. Owing to lack of efficacy, the treatment of constipation with classic drugs is inadequate for relieving bloating and other symptoms. Anyway, half of the patients were not satisfied with the effect of laxative for improving their superiority of lives [4-7]. Polyalthia suberosa (Roxb.) Thwaites is a shrub or small tree, which is grown and distributed both in Bangladesh and India [8-9] and locally recognized as Jam debharu or Ham jam [9-10]. The presence of corky barks, narrowly oblong or oblonglanceolate long acuminate shining leaves, rusty tomentose young branchlets etc. are the typical properties of this plant [11]. It is traditionally used as abortifacient, laxative, febrifuge, analgesic, as well as fillers of tooth cavities. Again, if the barks of the roots of this plant are mixed with Piper longum fruits, then puerperal fever can be healed. Furthermore, this plant has soporific, astringent, sedative, adaptogenic and diuretic properties [10].

Extensive review of literature revealed that Polyalthia suberosa (Roxb.) Thwaites (Annonaceae) leaves contained betasitosterol, alpha-and beta-amyrin, campesterol, lupeol as well as stigmasterol. Besides, Polyalthia suberosa (Roxb.) Thwaites also contained lanuginosine, alkaloids and oxostephanine. Likewise, suberosol and triterpene were found in the leaves and stems of this plant [12]. Additionally, this plant showed a variety of activities including analgesic, anti-inflammatory, cytotoxic, anti-HIV, antibacterial, neuropharmacological and antioxidant [9-10, 13-16].

But, Polyalthia suberosa (Roxb.) Thwaites has not been studied till now for its effectiveness in constipation by inducing laxation. So, the present study was designed to provide scientific evidence to the traditional use of this plant in the treatment of constipation by using diverse pharmacological models.

How to cite this article: Aziz MA, Yasmen N, Akter MI. Laxative effect of the crude methanolic extract of Polyalthia suberosa (Roxb.) Thwaites in mice. J Res Pharm. 2020; 24(5): 617-622. 


\section{RESULTS}

\subsection{Laxative activity test}

By laxative activity test, PSM was found to produce significant ( ${ }^{*} \mathrm{P}<0.05 \mathrm{vs}$. control) laxative activity at the tested doses $(200$ and $400 \mathrm{mg} / \mathrm{kg})$ at $0-8 \mathrm{~h}$ and $8-16 \mathrm{~h}$ respectively. It was noticed that the laxative effect of both of the tested doses was increased during 8-16 $\mathrm{h}$ as the weight of wet faeces was increased. At 8 $\mathrm{h}$, the wet faeces output of PSM $200 \mathrm{mg} / \mathrm{kg}$ was $2.80 \pm 0.20 \mathrm{mg}$, which was increased to $4.20 \pm 0.86 \mathrm{mg}$ at $16 \mathrm{~h}$. Moreover, PSM $400 \mathrm{mg} / \mathrm{kg}$ also incresead the weight of wet faeces from $3.40 \pm 0.68 \mathrm{mg}$ (at $8 \mathrm{~h}$ ) to $6.80 \pm 0.66$ $\mathrm{mg}($ at $16 \mathrm{~h})$. Similar trend was observed for the percentage of wet faeces by the above mentioned test doses. (Table 1).

\subsection{Laxative activity on loperamide induced constipation in mice}

The results of laxative activity on loperamide induced constipation in mice were summarized in table 2. Here, significant ( ${ }^{*} \mathrm{P}<0.05$ vs. control) laxative activity was noticed by PSM $400 \mathrm{mg} / \mathrm{kg}$ (Wet Faeces output was $4.80 \pm 1.28 \mathrm{mg}$ at $8-16 \mathrm{~h}$ ). Besides, dose dependant laxative activity was revealed by PSM 200 and $400 \mathrm{mg} / \mathrm{kg}$. From this table, it was clear that highest laxative activity was observed during late phase of fecal output $(8-16 \mathrm{~h})$.

\subsection{Gastrointestinal motility test in mice}

The results of gastrointestinal motility test showed that PSM 200 and $400 \mathrm{mg} / \mathrm{kg}$ produced significant ( ${ }^{*} \mathrm{P}<0.05$ vs. control) dose dependent laxative activity by increasing the movement of charcoal meal through the small intestine where, the distance travelled by charcoal meal was $118.20 \pm 5.42 \mathrm{~mm}$ and $132.80 \pm 6.66 \mathrm{~mm}$ consecutively for PSM 200 and $400 \mathrm{mg} / \mathrm{kg}$. Similar pattern was observed for the percentage of distance crossed by charcoal meal for both doses of PSM. Percentage of distance crossed by charcoal meal was found as $37.82 \pm 2.39 \%$ at a dose of PSM $200 \mathrm{mg} / \mathrm{kg}$, while it was $41.32 \pm 2.19 \%$ for PSM $400 \mathrm{mg} / \mathrm{kg}$ (Table 3).

Table 1. Laxative effect of PSM evaluated by laxative activity test.

\begin{tabular}{|c|c|c|c|c|c|c|c|}
\hline Group & Dose & $\begin{array}{c}\begin{array}{c}\text { Normal } \\
\text { faeces }\end{array} \\
\text { output } \\
(\mathrm{mg}) \\
0-8 \mathrm{~h}\end{array}$ & $\begin{array}{c}\text { Normal } \\
\text { faeces } \\
\text { output } \\
\text { (mg) } \\
8-16 \text { h }\end{array}$ & $\begin{array}{c}\text { Wet faeces } \\
\text { output } \\
\text { (mg) } \\
0-8 \mathrm{~h}\end{array}$ & $\begin{array}{c}\text { Wet faeces } \\
\text { output } \\
\text { (mg) } \\
8-16 \mathrm{~h}\end{array}$ & $\begin{array}{c}\begin{array}{c}\text { Percentage } \\
\text { of }\end{array} \\
\text { wet faeces } \\
0-8 \mathrm{~h} \\
(\%) \\
\end{array}$ & $\begin{array}{c}\text { Percentage } \\
\text { of } \\
\text { wet faeces } \\
8-16 \mathrm{~h} \\
(\%) \\
\end{array}$ \\
\hline Control & $\begin{array}{c}5 \\
\mathrm{~mL} / \mathrm{kg}\end{array}$ & $1.00 \pm 0.32$ & $1.20 \pm 0.20$ & $0.00 \pm 0.00$ & $0.00 \pm 0.00$ & $0.00 \pm 0.00$ & $0.00 \pm 0.00$ \\
\hline $\begin{array}{l}\text { Picosulfate } \\
\text { sodium }\end{array}$ & $\begin{array}{c}5 \\
\mathrm{mg} / \mathrm{kg}\end{array}$ & $4.20 \pm 0.86^{*}$ & $3.60 \pm 0.75^{*}$ & $5.40 \pm 0.87^{\text {*\# }}$ & $9.60 \pm 0.51^{* \# \$}$ & $57.10 \pm 2.81^{*}$ & $73.41 \pm 4.68^{*}$ \\
\hline PSM & $\begin{array}{c}200 \\
\mathrm{mg} / \mathrm{kg}\end{array}$ & $2.20 \pm 0.37$ & $2.40 \pm 0.40$ & $2.80 \pm 0.20^{*}$ & $4.20 \pm 0.86^{*}$ & $57.33 \pm 3.23^{*}$ & $63.26 \pm 2.30^{*}$ \\
\hline PSM & $\begin{array}{c}400 \\
\mathrm{mg} / \mathrm{kg}\end{array}$ & $3.00 \pm 0.71$ & $3.40 .4 \pm 0.68^{*}$ & $3.40 \pm 0.68^{*}$ & $6.80 \pm 0.66^{*}$ & $53.17 \pm 4.69^{*}$ & $68.24 \pm 4.19^{*}$ \\
\hline
\end{tabular}

Values are presented as mean \pm standard error, $\mathrm{n}=5$ mice in each group, ${ }^{*} \mathrm{P}<0.05$ vs. control (Dunnet's $\mathrm{t}-$ test), \# $\mathrm{P}<0.05$ vs. PSM $200 \mathrm{mg} / \mathrm{kg} \&$ \& $<0.05$ vs. PSM $400 \mathrm{mg} / \mathrm{kg}$ (Pair-wise comparison by post-hoc Bonferroni's test).

Table 2. Laxative effect of PSM evaluated by loperamide induced constipation in mice.

\begin{tabular}{|c|c|c|c|c|c|c|c|}
\hline Group & Dose & $\begin{array}{c}\text { Normal } \\
\text { faeces } \\
\text { output } \\
\text { (mg) } \\
0-8 \mathrm{~h}\end{array}$ & $\begin{array}{c}\text { Normal } \\
\text { faeces } \\
\text { output } \\
\text { (mg) } \\
8-16 \text { h }\end{array}$ & $\begin{array}{c}\text { Wet faeces } \\
\text { output } \\
\text { (mg) } \\
0-8 \mathrm{~h}\end{array}$ & $\begin{array}{c}\begin{array}{c}\text { Wet } \\
\text { faeces } \\
\text { output } \\
\text { (mg) }\end{array} \\
8-16 \mathrm{~h}\end{array}$ & $\begin{array}{c}\text { Percentage } \\
\text { of } \\
\text { wet faeces } \\
0-8 \mathrm{~h} \\
(\%)\end{array}$ & 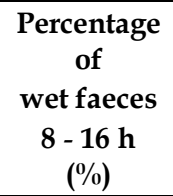 \\
\hline Control & $\begin{array}{c}5 \\
\mathrm{~mL} / \mathrm{kg}\end{array}$ & $0.40 \pm 0.24$ & $0.80 \pm 0.20$ & $0.00 \pm 0.00$ & $0.00 \pm 0.00$ & $0.00 \pm 0.00$ & $0.00 \pm 0.00$ \\
\hline $\begin{array}{l}\text { Picosulfate } \\
\text { sodium }\end{array}$ & $\begin{array}{c}5 \\
\mathrm{mg} / \mathrm{kg}\end{array}$ & $3.60 \pm 0.98^{*}$ & $4.40 \pm 0.93^{*}$ & $2.80 \pm 0.97^{*}$ & $5.40 \pm 1.36^{*}$ & $42.23 \pm 4.68^{*}$ & $51.42 \pm 8.47^{*}$ \\
\hline PSM & $\begin{array}{c}200 \\
\mathrm{mg} / \mathrm{kg}\end{array}$ & $1.80 \pm 0.58$ & $2.60 \pm 0.24$ & $1.20 \pm 0.37$ & $2.60 \pm 0.68$ & $33.00 \pm 9.43^{*}$ & $47.17 \pm 4.97^{*}$ \\
\hline PSM & $\begin{array}{c}400 \\
\mathrm{mg} / \mathrm{kg}\end{array}$ & $2.60 \pm 0.93$ & $3.40 .4 \pm 1.29$ & $2.00 \pm 0.89$ & $4.80 \pm 1.28^{*}$ & $34.00 \pm 10.30^{*}$ & $59.24 \pm 10.33^{*}$ \\
\hline
\end{tabular}

Values are presented as mean \pm standard error, $\mathrm{n}=5$ mice in each group, ${ }^{*} \mathrm{P}<0.05 \mathrm{vs}$. control (Dunnet's $\mathrm{t}-$ test). 
Table 3. Laxative effect of PSM evaluated by gastrointestinal motility test in mice.

\begin{tabular}{|c|c|c|c|c|}
\hline Group & Dose & $\begin{array}{l}\text { Total length of } \\
\text { small intestine } \\
(\mathrm{mm})\end{array}$ & $\begin{array}{l}\text { Distance crossed by } \\
\text { charcoal }(\mathrm{mm})\end{array}$ & $\begin{array}{c}\text { Percentage of distance } \\
\text { crossed by charcoal } \\
(\%)\end{array}$ \\
\hline Control & $5 \mathrm{~mL} / \mathrm{kg}$ & $314.00 \pm 5.10$ & $42.60 \pm 6.68$ & $13.60 \pm 2.18$ \\
\hline $\begin{array}{l}\text { Castor } \\
\text { oil }\end{array}$ & $\begin{array}{c}0.3 \\
\mathrm{~mL} / \text { mouse }\end{array}$ & $316.00 \pm 10.30$ & $159.80 \pm 9.39 * \#$ & $50.94 \pm 3.82^{* \#}$ \\
\hline PSM & $200 \mathrm{mg} / \mathrm{kg}$ & $314.00 \pm 6.78$ & $118.20 \pm 5.42^{*}$ & $37.82 \pm 2.39^{*}$ \\
\hline PSM & $400 \mathrm{mg} / \mathrm{kg}$ & $322.00 \pm 8.00$ & $132.80 \pm 6.66^{*}$ & $41.32 \pm 2.19^{*}$ \\
\hline
\end{tabular}

Values are presented as mean \pm standard error, $\mathrm{n}=5$ mice in each group, ${ }^{*} \mathrm{P}<0.05$ vs. control (Dunnet's $\mathrm{t}-$ test), ${ }^{\#} \mathrm{P}<$ 0.05 vs. PSM 200 mg/kg (Pair-wise comparison by post-hoc Bonferroni's test).

\section{DISCUSSION}

Fecal consistency depends on water holding ability of insoluble solids, which come from dietary fiber [17]. Laxatives, usually thought to perform by stimulating intestinal motility, which results in laxation. They induce fluid accumulation in the intestinal lumen by producing myoelectric alteration in intestinal smooth muscle and causing rapid evacuation. In addition, they also cause fluid accumulation in intestinal content by inhibiting ion and water absorption, stimulating fluid secretion or both concurrently. So, the volume of contents is increased and thereby increasing the frequency as well as ease of defecation $[3,18]$. Effect of PSM evaluated by laxative activity test exposes that PSM possesses laxative activity at both 200 and $400 \mathrm{mg} / \mathrm{kg}$.

Again, in the laxative activity of PSM assessed by loperamide induced constipation test in mice, constipation is persuaded by loperamide $\mathrm{HCl}$ through the inhibition of intestinal water secretion and colonic peristalsis. By this inhibition, faecal evacuation time is extended and intestinal luminal transit is delayed [3]. This study, demonstrated that PSM has laxative activity.

Excitation of cholinergic receptors of mice increases the peristaltic movement of their gastrointestinal tracts and these events may initiate the movement of charcoal meal [19]. Both neural and myogenic mechanisms are responsible for regulating intestinal transit [20]. Acceleration of intestinal propulsion is occurred by enhancing the contractile activity of smooth muscle layers, where several neurotransmitters and mediators operate these motor patterns. Acetylcholine acts as the main excitatory neurotransmitter in the enteric nervous system [21]. Thus, the presence of cholinomimetic constituents in the plant extract may explain the usefulness of it in constipation. Moreover, earlier studies showed that plants' laxative activities depend on the existence of phytocomponents such as tannins, flavonoids, alkaloids, terpenoids, phenolic compounds and sterols [5, 22]. Preliminary qualitative phytochemical screening of PSM revealed the presence of alkaloids and tannins [13]. Therefore, these phytoconstituents may be responsible for the laxative activity of PSM.

The results showed that PSM has ability to increase the propulsion of charcoal meal. PSM may show its laxative effect by stimulating intestinal motility, inducing fluid accumulation in the intestinal lumen as well as by stimulating fluid secretion.

\section{CONCLUSION}

The present study reveals that the oral administration of the PSM exhibited laxative activity. However, this finding needs extensive studies to disclose the exact chemical constituents and molecular mechanism of actions that are responsible for laxative activity of PSM.

\section{MATERIALS AND METHODS}

\subsection{Chemicals and reagents}

Loperamide hydrochloride, sodium picosulfate and castor oil were purchased from Square Pharmaceutical Ltd., Bangladesh; Acme Generics LLP, India as well as DLC Laboratories, USA respectively. Methanol of analytical grade was obtained from Merck, Germany which was used as solvent.

\subsection{Plant materials: collection and identification}

Through a broad literature review, Polyalthia suberosa (Roxb.) Thwaites (Annonaceae) was chosen for this research. However, leaves of this plant were accumulated from Phultala $\left(22.9750^{\circ} \mathrm{N}, 89.4583^{\circ} \mathrm{E}\right)$, Khulna, 
Bangladesh. Naymur Rahman who was the Principal Scientific Officer at the Bangladesh National Herbarium authenticated the recognised species. Besides, 44988 was the accession number of this plant in the same herbarium. Furthermore, the herbarium put down the dried sample.

\subsection{Preparation of the extracts}

The leaves were rinsed with water and dried in room temperature under a shaded area. Later, these were dried again through an air oven (LY-660, DONGGUAN LIYI test equipment co. ltd., China) at a reduced temperature (not more than $40^{\circ} \mathrm{C}$ ) and become suitable for grinding. Then leaves were ground using a high capacity grinding mill (Model 2000 LAB Eriez, USA) to make fine powders which were stored in an air- tight container. Here, the test extract was prepared through cold extraction procedure. The powdered plant materials ( $400 \mathrm{~g}$ of leaves) were taken in a clean, round bottomed flask ( 5 liters) and soaked in 4 liters of methanol (Mark, Germany) for 7 days. Whatman No.1 filter papers were used to filter the liquid extract. After that the filtrate was dried in air to get solid residues. The extraction yield of PSM was $12.34 \%$ $(\mathrm{w} / \mathrm{w})$ and the extract was kept at $4^{\circ} \mathrm{C}$ for further experiments.

\subsection{Experimental animals}

Sixty Swiss albino mice of either sex, 6-7 weeks of age, having weight 25-30 g, were collected from International Center for Diarrhoeal Disease Research Bangladesh, Mohakhali, Dhaka, Bangladesh. The experimental animals were kept under standard environmental conditions (temperature: $27.0 \pm 1.0^{\circ} \mathrm{C}$, relative humidity: 55-65\% and $12 \mathrm{~h}$ light/12 h dark cycle) with one week adaption prior to the experiment. They were housed in cages made of polypropylene and they had free access of feed and water ad libitum. However, all tests were conducted following the internationally recognised guidelines of Institute of Laboratory Animal Research [23]. All procedures for animal experiments were approved (Protocol No. ERC/FBS/JUST/2017-04) by the institutional animal ethical committee of Jashore University of Science and Technology, Jashore, Bangladesh.

\subsection{Evaluation of laxative activity}

\subsubsection{Laxative activity test}

Laxative activity test was performed according to Sharma et al. where mice were fasted for $12 \mathrm{~h}$ prior to the experiment and provided only water ad libitum. Twenty mice were divided into four groups, where the first group acted as the control group and received distilled water $(5 \mathrm{~mL} / \mathrm{kg}$, p. o.); picosulfate sodium (5 $\mathrm{mg} / \mathrm{kg}$ ) was administered orally to the second group and considered as positive control group; third and fourth group served as test groups which received PSM $200 \mathrm{mg} / \mathrm{kg}$ and $400 \mathrm{mg} / \mathrm{kg}$ orally. Total number of faecal (normal as well as wet faeces) output of all the experimental animals were monitored for $16 \mathrm{~h}$. Although water was provided to every mouse throughout the experiment, foods were only supplied to the animals after getting the data $(0-8 \mathrm{~h})$ of weight of wet faeces. Moreover, during the study, these amount of foods and water content were measured. In addition, during the experimental periods, every mouse was placed in cage individually that was lined with clean filter paper [19].

\subsubsection{Laxative activity on loperamide induced constipation in mice}

This study was conducted as described by Saito et al. Mice were grouped and treated as described before. Moreover, before the treatment, they were fasted for $12 \mathrm{~h}$, where the proper supply of water ad libitum was ensured. In addition, the mice were kept individually in cages with clean filter paper. However, one hour after the treatment, all of the experimental animals received Loperamide $\mathrm{HCl}(5 \mathrm{mg} / \mathrm{kg})$ orally. Here, the production of faeces (total weight of faeces, i.e., both normal as well as wet faeces) in all four groups was monitored for $16 \mathrm{~h}$. Besides, during the experiment, the amount of foods and water supplied to the mice were estimated [17].

\subsubsection{Gastrointestinal motility test in mice}

Gastrointestinal motility test in mice was performed as described by Mascolo et al. [24]. Twenty mice were divided into four groups and fasted for $12 \mathrm{~h}$ before the experiment while they were maintained with water ad libitum. Two of the groups were then treated with two doses (200 and $400 \mathrm{mg} / \mathrm{kg}$ p.o.) of the PSM which served as the test groups. One group served as blank or negative control treated with distilled water $(5 \mathrm{~mL} / \mathrm{kg}$, p.o.) and the remaining group took castor oil $(0.3 \mathrm{~mL} / \mathrm{mouse}$, p.o.) and acted as the positive control group. $30 \mathrm{~min}$ later of the respective treatment to different groups, each animal was given orally 0.3 
$\mathrm{mL}$ of freshly prepared $5 \%$ aquesous suspension of charcoal meal. Then, the mice were sacrificed by cervical dislocation after $30 \mathrm{~min}$ of charcoal administration. After that, the abdomen of these mice were cut and opened instantly. By this way, the whole small intestine (pylorus region to caecum) of mice was excised. Finally, the percentage or the charcoal transport ratio was found by calculating the length of the entire small intestine as well as the space between the forward-facing of the charcoal meal and the pylorus region.

\subsection{Statistical Analysis}

All the results are expressed as mean \pm S.E.M (Standard Error of Mean). Data were analyzed statistically by one-way ANOVA followed by Dunnett's $t$ test. Pair-wise comparison of means among the groups was analyzed by one-way ANOVA followed by post-hoc Bonferroni's test. $\mathrm{P}<0.05$ was considered to be statistically significant. SPSS software (version 17; IBM Corporation, New York, USA) was used to analyze data.

Acknowledgement: The authors are grateful to the Department of Pharmacy, Jashore University of Science and Technology, Jashore, Bangladesh for providing facilities to carry out the research work.

Author contributions: Concept - M.A.A., N.Y.; Design - M.A.A., N.Y.; Supervision - M.A.A.; Resources - M.A.A., N.Y., MIA.; Materials - N.Y., MIA.; Data Collection and/or Processing - M.A.A., N.Y., MIA.; Analysis and/or Interpretation - M.A.A., N.Y., MIA.; Literature Search - M.A.A, MIA.; Writing - M.A.A., N.Y., MIA.; Critical Reviews - M.A.A., N.Y., MIA.

Conflict of interest statement: The authors declared no conflict of interest.

Ethics committee approval: Institutional animal ethical committee of Jashore University of Science and Technology, Jashore, Bangladesh approved the protocol for animal experiments with the number of ERC/FBS/JUST/2017-04 on September 22017.

\section{REFERENCES}

[1] Nafiu MO, Abdulsalam TA, Jimoh RO, Kazeem MI. Ameliorative effect of Lecaniodiscus cupanioides (Sapindaceae) aqueous root extract in loperamide induced constipated rats. Trop J Pharm Res. 2015; 14: 1057-1062. [CrossRef]

[2] Higgins PD, Johanson JF. Epidemiology of constipation in North America: a systematic review. Am J Gastroenterol. 2004; 99: 750-759.

[3] Ashafa AOT, Sunmonu TO, Abass AA, Ogbe AA. Laxative potential of the ethanolic leaf extract of Aloe vera (L.) Burm. f. in Wistar rats with loperamide-induced constipation. J Nat Pharm. 2011; 2: 158-162.

[4] Golla U, Gajam PK, Bhimathati SS. Evaluation of diuretic and laxative activity of hydro- alcoholic extract of Desmostachya bipinnata (L.) Stapf in rats. J Integr Med. 2014; 12: 372-378. [CrossRef]

[5] Méité S, Bahi C, Yéo D, Datté JY, Djaman JA, N'guessan DJ. Laxative activities of Mareya micrantha (Benth.) Müll. Arg. (Euphorbiaceae) leaf aqueous extract in rats. BMC Complement Altern Med. 2010; 10: 7. [CrossRef]

[6] Johanson JF, Kralstein J. Chronic constipation: a survey of the patient perspective. Aliment Pharmacol Ther. 2007; 25: 599-608. [CrossRef]

[7] Bengtsson M, Ohlsson B. Psychological well-being and symptoms in women with chronic constipation treated with sodium picosulphate. Gastroenterol Nurs. 2005; 28: 3-12. [CrossRef]

[8] Kew Science. Plants of the world online. Accessed date: June 21, 2020.

[9] Mazumdar R, Rahman MH, Rahman MM, Chowdhury MAR, Hossain MA, Ahmed MS, Gupta PD. Phytochemical and pharmacological investigation of Polyalthia suberosa Roxb. Int J Innov Pharm Sci Res. 2016; 4: 693-708.

[10] Stuart GU. Duhat-matsing, Philippine medicinal plants. Accessed date: June 21, 2020.

[11] Kumar ESS, Krishnan SG, Murugesan K, Shailajakumari S. Notes on Polyalthia malabarica (Bedd.) I.M. Turner and Polyalthia suberosa (Roxb.) Thwaites (Annonaceae). Int J Bot Stud. 2016; 1(4): 27-28.

[12] Khare CP, Indian medicinal plants: an illustrated dictionary, 1st ed., Springer-Verlag, New York, USA 2007.

[13] Bellah SF, Ahmed F, Rahman AA, Shahid IZ, Hossen SMM. Preliminary phytochemical, anti-bacterial, analgesic, anti-diarrhoeal and cytotoxic activity of methanolic extract of Polyalthia suberosa leaves. Int J Pharm Sci Res. 2012; 5: 1322-1326. [CrossRef] 
[14] Labu ZK, Makshud M, Basir S, Uddin J, Biswas S, Sultana N. Study of phytochemical screening, antioxidant, antidiarrhoeal and analgesic activities of hydromethanol extracts of Polyalthia suberosa (Roxb.). J Biomed Pharma Res. 2013; 2(3): 52-63.

[15] Li HY, Sun NJ, Kashiwada Y, Sun L, Snider JV, Cosentino LM, Lee KH. Anti-AIDS agents, 9. Suberosol, a new C31 lanostane-type triterpene and anti-HIV principle from Polyalthia suberosa. J Nat Prod. 1993, 56(7): 1130-1133. [CrossRef]

[16] Yasmen N, Aziz MA, Tajmim A, Akter MI, Hazra AK, Rahman SMM. Analgesic and anti-inflammatory activities of diethyl ether andn-hexane extract of Polyalthia suberosa leaves. Evid Based Complement Alternat Med. 2018; 5617234. [CrossRef]

[17] Saito T, Mizutani F, Iwanaga Y, Morikawa K, Kato H. Laxative and antidiarrheal activity of polycarbophil in mice and rats. Jpn J Pharmacol. 2002, 89(2): 133-141. [CrossRef]

[18] Gaginella TS, Bass P. Laxatives: An update on mechanism of action. Life Sci. 1978; 23: 1001-1009. [CrossRef]

[19] Sharma S, Paliwal S, Dwivedi J, Tilak A. First report on laxative activity of Citrullus lanatus. Pharmacologyonline. 2011; 2: 790-797.

[20] Huizinga JD, Ambrous K, Der-Silaphet T. Co-operation between neural and myogenic mechanisms in the control of distension-induced peristalsis in the mouse small intestine. J Physiol. 1998; 506: 843-856. [CrossRef]

[21] Waterman SA, Costa M. The role of enteric inhibitory motoneurons in peristalsis in the isolated guinea-pig small intestine. J Physiol. 1994; 477: 459-468.

[22] Otshudi AL, Vercruysse A, Foriers A. Contribution to the ethnobotanical, phytochemical and pharmacological studies of traditionally used medicinal plants in the treatment of dysentery and diarrhoea in Lomela area, Democratic Republic of Congo (DRC). J Ethnopharmacol. 2000; 71: 411-423. [CrossRef]

[23] Institute of Laboratory Animal Resources, Commission on Life Sciences, National Research Council. Guide for the Care and Use of Laboratory Animals. National Academy Press, Washington, 1996, pp. 65, 21-48.

[24] Mascolo N, Izzo AA, Avtore G, Barboto F, Capasso F. Nitric oxide and castor oil induced diarrhea. J Pharmacol Exp Therap. 1994; 268: 291-295.

This is an open access article which is publicly available on our journal's website under Institutional Repository at http://dspace.marmara.edu.tr. 